\title{
THE EFFECTIVENESS OF GAME BRAIN STIMULATION ON PRE-SCHOOL CHILD DEVELOPMENT IN PAUD BABUSSALAM DS. PANDEAN KAB. TRENGGALEK
}

\author{
Evita Widyawati ${ }^{1}$, Byba Suhita ${ }^{2}$, Indasah ${ }^{3}$ \\ Postgraduate Program STIKes Surya MitraHusada Kediri \\ widyawatievita@gmail.com
}

\begin{abstract}
Development child in age preschool very important. Because on age this required for process development self and concept self in himself. In times this for support growth and its development required appropriate stimulation with age and is no make depressed on children. The objective was Knowing effectiveness stimulation brain games to preschooldevelopment child in PAUD BabussalamDesa Pandean KabupatenTrenggalek. The design used in research was quasiexperimental design. Population was child preschool in PAUD BabussalamDesa Pandean KabupatenTrenggalek. The sample ware 26 respondents on simple random sampling. Variables Independent research was stimulation brain games and variable dependent was development motor. Data collected with using DDST, then the data was analyzed use test Wilcoxon with level significance $\alpha \leq 0$, 05. Results research show that brain stimulation affects the game on significant on smooth motoric $(p=0.025)$, and coarse motor $(p=0.046)$, but no influence on development language $(p=$ $0.317)$ and psychosocial $(p=0.317)$. Before given the brain game, many respondents have DDST normal value as much as 21 respondents (80.8\%), and the suspect five respondents (19.2\%), while after given brain game that suspect DDST value decreases became one respondent (3.8\%). Results test statistics use Wilcoxon Signed Test Range obtained that $p=0.046$, which means that affects the brain game on significant DDST against children. Conclusion from research this was Brain Game is effective in improving the ability of Childhood Development Pre-School.
\end{abstract}

Keywords: DDST, Developments Child, Brain game. 
INTRODUCTION

Health is an investment to support development economic as well as having important role in the effort poverty alleviation. To get quality resources need to be prepared early, especially in the age of five. Healthy policies and regulations through a life-cycle approach to achieving healthy families, the age of infants and toddlers become one of the priorities through the provision of developmental stimulation. Due in 0-4 years age range intellectual development increased by about $50 \%$, and the age of $4-8$ years developed into a $80 \%$ (Musarafoh, 2011).

The development of a child is the increasing skill (ability) in the structure and the more complex body functions in an orderly and predictable pattern, because of the maturation process. Here involves the process of differentiation of the body's cells, body tissues, organs, and organ systems that develop in such a way that each can fulfill its function. This includes emotional, intellectual and behavioral developments because of interaction with the environment (Soetjiningsih, 2012). Ministry of Health of the Republic of Indonesia (2009) mentioned aspects of child development that can be monitored include coarse motion, smooth motion, speech and language, and socialization and independence.

The child develops from various aspects of his physical development, both gross and fine motor, developing cognitive aspects, social and emotional aspects. The development of children in pre-school age is very important. Because at this age is necessary for the process of selfdevelopment and self-concept in him. In these times to support its growth and development requires age-appropriate stimulation and is not stressful in children (John W. Santrok, 2011).

According to UNICEF in 2011, data on the high incidence of growth and developmental disorders in children under five years is found $(27.5 \%)$ or 3 million children are affected. World health organization (WHO) reports that 5-25\% of preschool aged children suffer from minor cerebral dysfunction (Widati, 2012). Meanwhile, according to (Kay-Lambkin, et al, 2007) globally reported children who experience anxiety disorders around 9\%, easy emotional $11-15 \%, 9-15 \%$ behavioral disorder. The Indonesian Ministry of Health reported that 0.4 million $(16 \%)$ of under-fives underwent developmental disruption, both fine and gross motor development, hearing impairment, lack of intelligence and speech delay. Meanwhile, according to East Java Health Service in (Widati, 2012) amounted to 85,779 (62.02\%) preschool children experiencing developmental disorders. Solihin et al. (2013) showed that cognitive development rate $(54.8 \%)$ and fine motor $(68.5 \%)$ were low and the children's motor development rate was moderate $(41.1 \%)$.

Based on preliminary survey by researcher at PAUD Babussalam there are 102 preschool children. From the data obtained to stimulate child's motor development in PAUD Babussalam has done various activities such as sticking with the media of banana leaves, cutting and folding origami paper. Evaluation of $19.6 \%$ of the development of the semester was $19.4 \%$ developing (MB), $31.8 \%$ developing as expected (BSH) and $19.6 \%$ developing very well. The percentage obtained from it can be concluded that the necessary stimulation applied DAPT other to support the child's development with the aim of undeveloped and that started to develop can be developed very well.

Brain game or also called the game of the brain can simply be interpreted with a useful game to optimize the power of the brain. Brain games can dismiss the perception of parents that to stimulate child development should be by using an expensive game tool (Syamsuddin, 2014). 


\section{METHOD}

Design is all the necessary process in planning and conducting research. The research design used was quasi experimental design with "time series design" model (Sugiyono, 2011). Researchers analyzed the effectiveness of the stimulation Brain Game against the child's development that includes the development of fine motor, gross motor, language and psychosocial development.

\section{Results and Discussion}

\section{Analyze development motor smooth Before and after given Brain Stimulation Game}

Table 1. Frequency Distribution of Fine Motor Development of PreSchool Age Children given before and after stimulation in early childhood Brain Game in PAUD BabussalamDesa Pandean KabupatenTrenggalek on 04 September - 23 September 2017

\begin{tabular}{ccccc}
\hline Fine Motoric & \multicolumn{2}{c}{ Pre } & \multicolumn{2}{c}{ Post } \\
Development & n & \% & n & \% \\
\hline Normal & 20 & 76,9 & 25 & 96,2 \\
Suspect & 6 & 23,1 & 1 & 3,8 \\
\hline Total & $\mathbf{2 6}$ & $\mathbf{1 0 0}$ & $\mathbf{2 6}$ & $\mathbf{1 0 0}$ \\
\hline
\end{tabular}

The result of the research shows that before given the brain game most of the respondents have normal fine motor development as much as 20 respondents $(76,9 \%)$, and the suspect 6 respondents $(23,1 \%)$, The result of research got that after given brain game of fine motor development suspect initially 6 respondents $(23.1 \%)$ decreased to one respondent $(3.8 \%)$, based on the results of the study showed that the brain stimulation significantly affect the game in fine motor skills $(\mathrm{p}=0.025)$.

Development and growth of Age preschool is age development child between age three up to five years. On age this happen significant changes for prepare style life that is sign in school with combine between development biological, psychosocial, cognitive, spiritual and achievement social. Child on time preschool have awareness about him as man or women can set self in toilet training and know some a dangerous thing and harmful himself. One of the factors affecting development is gender. Respondents were mostly female $(61.54 \%)$. The reproductive function in girls develops faster than men. However, after passing through puberty, the growth of boys will be faster (Adriana, 2013) All respondents have sufficient monthly birth status according to Adriana, 2013 that development is determined by prenatal factors. This is supported by the results of research that the majority of respondents have smooth motor development, gross motor, language and normal psycho social behavior, although there are some who suspect. This may be due to postnatal factors. As stated by Adriana, 2013 that further development can be influenced by nutrition to grow baby flowers, adequate nutrients are needed, the environment where the child lives serves as provider of basic needs of the child (provider). Inadequate environmental sanitation, lack of sunlight, exposure to radioactive rays and certain chemicals ( $\mathrm{Pb}$, Mercury, cigarettes, etc.) have a negative impact on child growth. Other factors that can influence that different socioeconomic, poverty is always concerned with the lack of food and poor environmental health and ignorance, inhibit the growth of children. A nurturing environment, mother-child interaction greatly affects the child's growth and development. Stimulation Development requires stimulation or stimulation, especially in the family, such as the provision of toys, the socialization of children, and the involvement of mothers and other family members of the child's activities. These conditions allow the condition of the child to remain in a state of suspect at some stage of its development. 


\section{Analyze gross motor development Before and after brain game stimulation}

Table 2. Frequency Distribution of Motor Abusive Childhood Development Preschool given before and after Brain Gamestimulationin PAUD BabussalamDesa Pandean KabupatenTrenggalek on 04 September - 23 September 2017

\begin{tabular}{ccccc}
\hline Rough Motor & \multicolumn{2}{c}{ Pre } & \multicolumn{2}{c}{ Post } \\
Condition & n & \% & n & \% \\
\hline Normal & 21 & 80,8 & 25 & 96,2 \\
Suspect & 5 & 19,2 & 1 & 3,8 \\
\hline Total & 26 & 100 & 26 & 100 \\
\hline
\end{tabular}

The result of the research shows that the normal gross motor development was 21 respondents $(80,8 \%)$, and the suspect 5 respondent $(19,2 \%)$, the motor development was suspect that initially 5 respondents $(19,2 \%)$ decrease to 1 respondent $3.8 \%$ ), Based on the results of the study showed that brain game stimulation significantly influences on the rough and motor $(\mathrm{p}=0.046)$.

Gross Motor (movement motor rough) was related Aspects with movement and attitude body. On age this happen significant changes for prepare style life that was sign in school with combine between development biological, psychosocial, cognitive, spiritual and achievement social. Child on time preschool have awareness about him as man or women can set self in toilet training and know some a dangerous thing and harmful him (Mansur, 2011). Snowman (in Patmonodewo, 2008) suggests features of preschoolers (3-6 years old) who are usually in kindergarten. The characteristics expressed include the physical, social, emotional and cognitive aspects of the child. According to Whalley and Wong (2008), child development preschool in for on development personality and development mental function. Development personality composed from development psychosocial, development psychosexual, and mental development. Crisis facing child on ages 3 and 6 years in call "initiative versus guilt". Where person nearest child age preschool is family, normal children have dominate feeling autonomy, children develop a sense of guilt when person old make child feel that his imagination and activity no could tolerate scanning satisfaction in period first. Development Psychosexual On stage this child preschool including on stage phallic, where time this genital into the body area of interest and sensitive (Hidayat, 2008). According to Whalley and Wong (2008), in development cognitive wrong one tasks related with period preschool is readiness for school and lesson school.

\section{Analyze development language Before and after given brain gamestimulation}

Table 3. Frequency Distribution Childhood Language Development Preschool Before and After given Brain Game stimulationin PAUD BabussalamDesa Pandean KabupatenTrenggalek

\begin{tabular}{ccccc}
\hline Language & \multicolumn{2}{c}{ Pre } & \multicolumn{2}{c}{ Post } \\
Development & n & \% & N & \% \\
\hline Normal & 24 & 92,3 & 25 & 96,2 \\
Suspect & 2 & 7,7 & 1 & 3,8 \\
\hline Total & $\mathbf{2 6}$ & $\mathbf{1 0 0}$ & $\mathbf{2 6}$ & $\mathbf{1 0 0}$ \\
\hline
\end{tabular}

The results of the study before the intervention found that the normal language development as much as 24 respondents $(92.3 \%)$, and that suspect 2 respondents $(7.7 \%)$, and after the intervention found that the development of language that suspect initially 2 respondents $(7.7 \%)$ decreased to 1 respondent $(3.8 \%)$, based on the results of the study showed that brain game stimulation significantly influence the development of language ( $p=0,317)$.

Language as tool communication no only form talk, can realized with sign gesture hand or member body others who have rules itself growing be communication through speech right and clear. In talking about development 
language There are three items that need to be discussed (Patmonodewo, 2008), namely There is difference between language and ability talk. Language usually understood as system complicated language and is semantics, while ability talk composed from expression in form words. Although language and ability talking very close the relationship but both different. There is two area growth language that is language that is understanding / receptive (understanding) and statement / expressive (producing). Language sense (e.g. listen and read) show ability child for understand and apply to a communication addressed to child The. Language expressive (speaking and writing) shows creation language communicated to others. Communication self or talk in heart, too must discussed. Child will be talking with him own if imagining, in moment plan complete problems, and harmonize movement them. Child age preschool usually has able develop skills talk through conversation can charming others. They could use language with various means, among other things, asked, dialogue and sing.

\section{Analyze development psychosocial Before and after given brain gamestimulation}

Table 4. Psycho Behavior Frequency Distribution of Social Development Pre-School Age Children Before and After givenBrain Game Stimulation in PAUD BabussalamDesa Pandean

KabupatenTrenggalekon $\quad 04$ September - 23 September 2017

\begin{tabular}{ccccc}
\hline $\begin{array}{c}\text { The Development of } \\
\text { Social Psycho }\end{array}$ & \multicolumn{2}{c}{ Pre } & \multicolumn{2}{c}{ Post } \\
Behavior & n & \% & n & \% \\
\hline Normal & 23 & 88,5 & 24 & 92,3 \\
Suspect & 3 & 11,5 & 2 & 7,7 \\
\hline Total & $\mathbf{2 6}$ & $\mathbf{1 0 0}$ & $\mathbf{2 6}$ & $\mathbf{1 0 0}$ \\
\hline
\end{tabular}

Based on the result of the research before the intervention it was found that the development of normal psycho social behavior were 23 respondents $(88,5 \%)$, and the suspect 3 respondents $(11,5 \%)$. The results showed that most respondents have DDST normal value as much as 21 respondents $(80.8 \%)$, and the suspect five respondents (19.2\%). Results research obtained too that Psycho-social development of the suspect initially three respondents $(11.5 \%)$ decreased to 2 respondents $(7.7 \%)$. The results obtained that after given the brain game DDST value suspect initially 5 respondents (19.2\%) decreased to 1 respondent $(3.8 \%)$.

Simply put Brain games can be interpreted with a game that is useful to optimize the workings of the brain. In other words, Brain Game was not just a game that was fun, but it also has a double benefit. Namely, as well as stimulation to help develop the sharpness (HaeriahSyamsuddin, 2014: 5). Brain Games can be done anywhere, inside or outside the room (indoor and outdoor activity) depending on the type of game. Ministry of Health of the Republic of Indonesia (2009) mention aspects of development that can be monitored include coarse motion, smooth motion, speech and language skills, and socialization and independence. Rough or coarse motion is an aspect related to a child's ability to move and posture involving large muscles, such as sitting, standing, and so on. Subtle or fine motor motion is an aspect related to a child's ability to perform movements involving specific body parts and performed by small muscles, but requires careful coordination such as observing things, squeezing, writing and so on. Speech and language skills are aspects related to the ability to respond to voice, talk, communicate, follow orders and so on. Socialization and independence are aspects related to the child's selfsufficiency (self-feeding, clearing toys, playing games), separating from mother / caregiver, socializing and interacting with the environment, and so on. 
Wilcoxon Statistics Test

Brain stimulation effectiveness Games on the development of pre-school children in PAUD BabussalamDesa Pandean KabupatenTrenggalek.

Table 5. Effectiveness Brain Gamestimulation in PAUD BabussalamDesa Pandean KabupatenTrenggalekon 04 September - 23 September 2017

\begin{tabular}{|c|c|c|c|c|}
\hline & & $\mathrm{N}$ & $\begin{array}{l}\text { Mean } \\
\text { Rank }\end{array}$ & $\begin{array}{l}\text { Sum of } \\
\text { Ranks }\end{array}$ \\
\hline \multirow{4}{*}{$\begin{array}{l}\text { Motorik_halus_ } \\
\text { post - } \\
\text { Motorik_halus_ } \\
\text { pre }\end{array}$} & Negative Ranks & 5 & 3,00 & 15,00 \\
\hline & Positive Ranks & 0 &, 00 & 00 \\
\hline & Ties & 21 & & \\
\hline & Total & 26 & & \\
\hline \multirow{4}{*}{$\begin{array}{l}\text { Perkembangan_ } \\
\text { bahasa_post - } \\
\text { Perkembangan_ } \\
\text { bahasa_pre }\end{array}$} & Negative Ranks & 1 & 1,00 & 1,00 \\
\hline & Positive Ranks & 0 & ,00 & 00 \\
\hline & Ties & 25 & & \\
\hline & Total & 26 & & \\
\hline \multirow{4}{*}{$\begin{array}{l}\text { Motorik_kasar_ } \\
\text { post - } \\
\text { Motorik_kasar_- } \\
\text { pre }\end{array}$} & Negative Ranks & 4 & 2,50 & 10,00 \\
\hline & Positive Ranks & 0 &, 00 & 00 \\
\hline & Ties & 22 & & \\
\hline & Total & 26 & & \\
\hline \multirow{4}{*}{$\begin{array}{l}\text { Psikososial_post - } \\
\text { Psikososial_pre }\end{array}$} & Negative Ranks & 1 & 1,00 & 1,00 \\
\hline & Positive Ranks & 0 &, 00 & 00 \\
\hline & Ties & 25 & & \\
\hline & Total & 26 & & \\
\hline \multirow{4}{*}{$\begin{array}{l}\text { DDST_post - } \\
\text { DDST_pre }\end{array}$} & Negative Ranks & 4 & 2,50 & 10,00 \\
\hline & Positive Ranks & 0 & ,00 & , 00 \\
\hline & Ties & 22 & & \\
\hline & Total & 26 & & \\
\hline
\end{tabular}

\begin{tabular}{|c|c|c|c|c|c|}
\hline & $\begin{array}{c}\text { Motorik_ } \\
\text { halus }\end{array}$ & $\begin{array}{c}\text { Perkembanga } \\
\text { n_bahasa }\end{array}$ & $\begin{array}{c}\text { Motorik_ } \\
\text { kasar_ }\end{array}$ & $\begin{array}{c}\text { Psikososia } \\
1\end{array}$ & DDST \\
\hline $\bar{Z}$ & $-2,236^{a}$ & $-1,000^{\mathrm{a}}$ & $-2,000^{a}$ & $-1,000^{\mathrm{a}}$ & $2000^{-}$ \\
\hline $\begin{array}{l}\text { Asym } \\
\text { p. Sig. } \\
\text { (2- } \\
\text { tailed) }\end{array}$ & ,025 & 317 & ,046 & ,317 & ,046 \\
\hline
\end{tabular}

a. Based on positive ranks.

b. Wilcoxon Signed Ranks Test

Based on Table 4.10 shows that stimulation Brain Game significantly affect the smooth motoric $(\mathrm{p}=0.025)$, and gross motor skills $(\mathrm{p}=0.046)$, but did not affect the development of language $(p=0.317)$ and psychosocial $(\mathrm{p}=0.317)$. Brain Games before being given the most respondents have DDST normal value as much as 21 respondents $(80.8 \%)$, and the suspect five respondents (19.2\%), while after being given a Brain Game DDST the suspect value decreases to 1 respondent $(3,8 \%)$. Statistical test results using Wilcoxon Signed Range Test with a $<0.05$ was found that $\mathrm{p}=0.046$, which means that $\mathrm{p}<\mathrm{a}$, so Brain Game significantly affect the child DDST.

\section{Conclusion}

The results showed that brain games before being given most respondents have fine motor development that suspect 6 respondents $(23.1 \%)$, after being given a brain game obtained fine motor development that suspect dropped to one respondent $(3.8 \%)$. Based on statistical tests showed that the stimulation of brain games significantly affect the fine motor $(\mathrm{p}$ $=0.025$ )

The result of the research shows that before given the brain game most respondents have gross motor development which suspect 5 respondents (19,2\%), after given brain game decrease to 1 respondent $(3,8 \%)$, Based on statistical test show that stimulation of brain game influence significantly in coarse motor $(\mathrm{p}=0.046)$.

The result of the research was that before given the brain game most of the respondents have the development of language that suspect 2 respondents $(7,7 \%)$, after given brain game decrease to 1 respondent $(3,8 \%)$, Based on statistical test show that stimulation of brain game does not influence significantly on language development $(\mathrm{p}=0.317)$

The result of the research shows that before given the brain game most of the respondents have the development of psycho social behavior which suspect 3 respondents $(11,5 \%)$, after given the brain game decrease to 2 respondents $(7,7 \%)$. Based on statistical tests indicating that brain game stimulation did not significantly affect the psychosocial $(p=0.317)$.

\section{Suggestion}

1. For Health Institution and Research Place 
The results can be an input in the effort to grow flowers in pre-school children related to fine motor development, rough, social psychology and language.

2. For the Community

The results of the study can be used as resources to support the development of the importance of stimulation in children that can be done with games brain stimulation (brain games).

3. For Health Education Institutions

The results of the study can be developed in midwifery science and can be used as one reference for further research that was with a combination of other interventions.

\section{Reference}

Ati, Choirunnisa Adhi dan Dera Alfiyanti, Achmad Solekhan. 2013. Hubungan antara Status Gizi Dengan Perkembangan Motorik Kasar Anak Balita di RSUD Tugurejo Semarang Tahun 2013. Semarang : Program Studi S1 Ilmu Keperawatan STIKES Telogorejo Semarang

Cristiana, Marta. 2015. Pengaruh Permainan Lego Adu Cepat terhadap Perkembangan Motorik Halus Anak Kelompok A di Tk Aisyiyah 3 Surabaya. Surabaya : Program Studi PG-PAUD, Fakultas Ilmu Pendidikan, Universitas Negeri Surabaya

Cuacicha, Frida Citra. 2016. Pengaruh Bermain Lempar Tangkap Bola terhadap Motorik Kasar Anak Kelompok B di Tk Pertiwi Sumber rejo Kota gajah Lampung Tengah. Lampung : Pendidikan Guru Pendidikan AnakUsia Dini Fakultas Keguruan dan Ilmu Pendidikan Universitas Lampung

Erlinda, Eva Imania. 2014. Brain Games (Mari Bermain Otak dengan Senam Otak). Yogyakarta :Volunteer'S Week di Sd Budi Mulia Dua
Eliasa. 2007. Brain Gym, Brain Games (Mari Bermain Otak dengan Senam Otak)

Febrianingsih. 2014. Tingkat Pencapaian Perkembangan Motorik Halus Anak Tk Aba Kelompok B Se-Kecamatan Minggir Sleman Yogyakarta. Yogyakarta : Program Studi Pendidikan Guru Pendidikan Anak Usia Dini Jurusan Pendidikan Prasekolah dan Sekolah Dasar Fakultas Ilmu Pendidikan Universitas Negeri Yogyakarta

Haryani. 2014. Efektivitas Penerapan Terapi Bermain Bola Untuk Meningkatkan Kemampuan Motorik Kasar Pada Tuna grahita Ringan Kelas 1 SMPLB. Surabaya : Program Studi Psikologi Universitas Negeri Surabaya

Khusna. 2015. Hubungan Status Gizi Dengan perkembangan Motorik Halus pada Anak Usia 1-3 tahun di Desa Tabu mela kecamatan Tilango Kabupaten Gorontalo.

Haryani 2013. Faktor-Faktor yang Berhubungan dengan Perkembangan Motorik Anak Usia PraSekolah. Jakarta :Poltekes Kemenkes

Melyloelha. 2015. Hakikat Perkembangan Motorik Halus Anak Usia Dini. http://www.balokedukasi.com/sejarah -lego

Notoatmodjo. 2010. Metodologi Penelitian Kesehatan Ed Revisi. Jakarta :Rineka Cipta.

Nur, Annisa. 2016. Pengaruh Kegiatan Bermain Kolase Terhadap Kemampuan Motorik Halus Anak Kelompok B di Tk Al-Azhar 7 Natar Lampung Selatan Tahun Pelajaran 2015/2016. Lampung :Fakultas Keguruan dan Ilmu Pendidikan Universitas Lampung Bandar Lampung 
Renita. 2015. Tingkat Pencapaian Perkembangan Motorik Halus Anak TK ABA Kelompok B se-Kecamatan Minggir Sleman Yogyakarta. http://eprints.uny.ac.id/13471/1/SKRI PSI.pdf

Haeriyah Syamsuddin. 2014. Brain Game untuk Balita. PT Buku Seru. Jakarta.

John W. Santrock. 2011. Masa Perkembangan Anak Edisi 11 Buku 2. Jakarta : Salemba Humanika.

Soetjiningsih. 2012. Tumbuh Kembang Anak. Jakarta : EGC.

Sugiyono. 2009. Metode Penelitian Bisnis. Cet. kesebelas. Bandung : CV Alfabeta.

Ahmad Susanto. 2011. Perkembangan Anak Usia Dini. Jakarta: Kencana Prenada. Media Group.

Wahyuni, Ade Sri \&Siska Damaiyanti2, Nurafni, Viona Putri Mayang Sari, Rahmad Ridwan, Afrina Susanti. 2014. Pelaksanaan Senam Brain Gym terhadap Tingkat Kecerdasan Emosional Anak Usia Prasekolah (45 Tahun) di Paud Ibnu Sina Bukit tinggi. Bukit tinggi :Pengajar Program Studi S1 Keperawatan STIKes Yarsi Sumbar Bukittinggi 